\title{
SOCIO ECONOMIC KISARAN BARAT COMMUNITY MAPPING IN ASAHAN REGENCY
}

\author{
Saleh Malawat ${ }^{1}$, M. Umar Maya Putra ${ }^{2}$ \\ Department Of Management, University of Asahan \\ Department Of Management, University Of Al Azhar Medan \\ umar_yazli@yahoo.com ${ }^{2}$
}

\begin{abstract}
This study aimed to analyze the socio economic community mapping with a case study community district of Kisaran Barat. The problem in this research is to see how far the characteristics ability social economic district of Kisaran Barat such as the business category, inspiration opening of enterprises, business development, year to start a business, age of respondents, total labor, type help business bevelopment, type help expected agencies private / state which is part of the social economic mapping in Asahan. The data used is primary data using questionnaires to the communities of Kisaran Barat from May to June 2015. While the methods of analysis used for primary data and secondary data obtained on a general overview Kisaran Barat of range and the results of the study of literature (Library Research), which is used as a support theories relevant to the research. From the results of this study indicate that the business category is making bricks, inspiration opening business: the ages business effort, business development: fluctuatively, year to start a business: In 1970, age of respondents is over 50 years, total workforce: 1 labor, type of business development assistance: no aid, types of help expected private agencies/government one: capital, training, marketing.
\end{abstract}

\section{Keyword: Mapping,Kisaran Barat, Asahan}

\section{INTRODUCTION}

The total population of 64.021 inhabitants Asahan with the number of men: 29694.340 .327 inhabitants and the number of women heads of family life and total: 13847 heads of household. Of the large number of the main potential is obtained Bricks Manufacturing Industry in the region and the Trade Sector Sidodadi that adorn crossings Tjokroaminoto, Jalan Sibogat seputaran Regent Office and several places in Jalan Diponegoro. Total female labor force that is greater in the male labor force, making a potential that can be developed to empower women through activities such as Family Welfare Education which is structured as crafts, baking with. The synergized through Business Link is located in North Sumatra. [1]

This means there is no innovation and creativity in making an advancement of the industry. Imitation concept of regions or provinces, can be used as an early stage to start a business or industry was the inspiration for starting a business more innovative and strengthen the brand image of a business. With the inspiration and imitation, can do the process of innovation of existing products, that will create a diversified product and has a high business value when competing on market mechanisms.

Social economic mapping concept comes to the business sector to make every community Asahan need cracker mind (reformer). Cracker in the development of a concept of trading according to Khasali divided into two categories. First, the global cracker who changed the landscape and global paradigm. Second, local cracker who changed the face, maps, and the industrial landscape in the region. They were inspired by events in other industries and different regional. However, if the global cracker capable of creating a global paradigm? How big is the change? Be a cracker would have to understand the values required generally to the public. Sometimes the building industry just as it went along and did not think long-term. Long-term process that can be considered is how the demand for a product in the present line with existing business synergies. Industry requires continuous innovation. [2]

The main issues that will be examined are:

1. The extent to which the socio-economic development of the community mapping Asahan and potential that could be developed?

2. What recommendations are used to enhance the economic development of society Asahan? 
Natural social work perspective, there are three approaches that can be used to improve social welfare, namely: [3]

1. Social philanthropy that relies on private donations, volunteers and non-profit organizations to meet the needs, find solutions to social problems, and create new social opportunities

2. Social work who rely on professionals to support the objectives of social welfare

3. Social administration which depend on government intervention through social services official.

In an effort to improve social welfare, social philanthropy is one effort that is often done in Indonesia. Social philanthropic activities undertaken both individuals, groups, communities, mass media widely used for education (scholarships), health, distribution of food, disaster victims, assistance for child-delivery, social conflict and social unrest. However, the number of donations provided are not sufficient, when compared with the large number of people who need assistance. There are still many citizens who are economically not yet moved to donate most of his wealth to help those who need help. For the spirit of social solidarity must be constantly nurtured and turned on. The attitude of social solidarity should be maintained in order to increasingly entrenched in our society. Instead attitude individualistic attitudes are indifferent to the suffering of others was time left.

To improve a company's development, we need an education that affect the research and development. On the previous research has shown that, although small companies are generally less likely to engage in research and development of large companies so they tend to use their innovative input more efficiently than large companies. [3]

If innovation included in the research and development (R\&D) to get optimal results, it's required capital aspect of small medium entreprises to minimize unemployment. Academic research has highlighted the role of entrepreneurship and venture capital in stimulating innovation. Hundreds, if not thousands, of papers have examined the relationship between firm size and innovation. Much of this work has related measures of innovative discoveries-for example, $R \& D$, expenditures, patents, or invention to firm size. [4]

The positive from the growing of civilizations can be concluded:

1. The growing enables the additional of labor force from time to time.

2. The additional of civilizations give them education to be labor that can gain not only expert one but also skilled, educated, and entrepreneur. [5]

\section{METHOD OF RESEARCH}

The methodology used is qualitative method, which the researchers presented directly on the recommendations of the socio-economic mapping descriptively. In making the Social Economic Community mapping Asahan using primary sources and secondary sources.

Primary source is a data source that directly provide the data to the data collector is the secondary source is a source that does not directly provide data to data collectors, for example through others or through documents. The resulting document can be through Centered Statistic and the data from Asahan Government website which has structured the data to make effective results in policy decisions. [6]

\section{RESULT OF RESEARCH}

\section{Characteristics Of The Community's Ability Kisaran Barat District}

Kisaran Barat has the ability of each to increase the potential advantages of the area. There are some things that look directly that became a clear picture portrait western range if we go through this area thoroughly. From the foregoing description we get the juice manufacturing industry around the Pick Up, Making Bricks, General Trading, the need also that are characteristic of Asahan namely the creation of Batang Red Sugar Palm unproductive.[7] are as follows:

Some other things we need to discuss, how in general of Kisaran Barat society's ability range 


\section{Business Category}

Of the 88 survey respondents who do good Western Range, the area near West Range: The range of alternative Cluster Eastern and obtained some results from business category, which is a potential Asahan in general and that of the Western range, namely:

a. Making Bricks totaling 35\% of the total respondents and the proceeds of this sale also includes commodities that are produced in the Village Sidodadi District of West Range. Enterprises are hereditary, is indeed capable of sustaining the family economy, but they can only produce enough or commonly called the results fit, could not do saving (Savings) and every entrepreneur bricks must have other sideline businesses that met the family's needs.

b. General trade amounting to $30 \%$ of the total respondents and a general business like selling fried noodles, fried rice, martabak bangka, noodle soup, coffee rice, shop grocery, a private radio station that always adorn the village new range District of Kisaran Barat, but the lack of coordination tight and sales patterns only impressed bandwagon and created due to make ends meet.

c. Juice sales Roving which amounted to $17 \%$ and has office hours from 11:00 s.d 23.00. This selling used pickup that stay in place all $\mathrm{jl}$. cokroaminoto and very loved by the people shavings because the price is cheap and made in a typical beverage packing.

Several other business category that exists is the manufacture of shoes bunut by $12 \%, 6 \%$ herbal making.

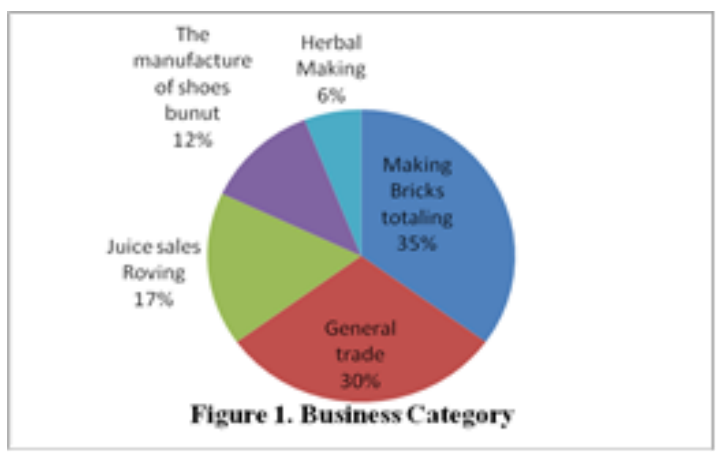

Figure 1. Business Category

\section{Inspiration Opening of Enterprises}

Efforts made by the western range have special inspiration which is the basis why the effort made. Generally a tough businessman, when asked about this, certainly not hesitate to answer because of the strong intention and effort carried out by using a Business Plan that has been structured so that already take into account how his business grew. Following the opening of the inspiring work done by the people of Kisaran Barat :

a. The ages business effort as much as $42 \%$ because this business is inherited from parents and what was done by the old oarng an imitation process (mimic) directly and the lack of innovation directly so impressed the conventional and the results obtained are sometimes less is absorbed directly by consumers.

b. Employment as much as $22 \%$ due to the difficulty to find a job and the least capacity to sit in the chair of Civil Servants (PNS), which is a position that idolized by society in general Asahan.

c. To improve marketing as much as $17 \%$. It becomes a creative thought in which every business would like to try innovative ways of business, but the lack of guidance from the government and also the importance of the private sector's role in taking this opportunity, as a way of increasing the brand image of an existing company

Some other things also the inspiration of the opening of the business is innovation creativity $11 \%$ and Study of Parents of $8 \%$. 


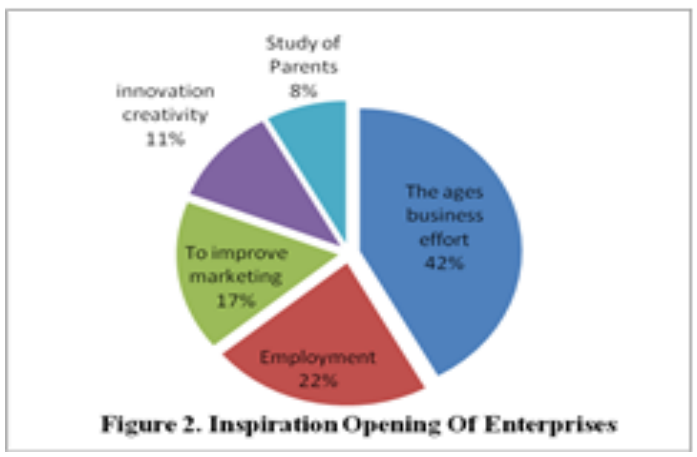

Figure 2. Inspiration Opening of Enterprises

\section{Business Development}

The development effort is in the western range, could not be categorized forward. From some businesses studied, many businesses are hereditary and there are many imitations patterns become part of an existing industry. This is certainly, in some effort caused the road somewhere. Some businesses studied business developments as follows:

a. Up and Down as much as $40 \%$ due to the game of middlemen who play the price, so the price is not conducive and the lack of focused attention of the government towards sustainable development. In other words, the rise and fall of business into something that was adapted by the business to make a living

b. Growing enough as much as $35 \%$ which results in lack of innovation and too many businesses with similar business so difficult step to more turnover of

c. Compete in terms of price as much as $13 \%$ because some industries are cheaper in terms of price but the lack of models among consumers resulted in several top level difficult to reach.

Some of the other responsibilities that become respondents are Rises $6 \%$, still way in the $4 \%$ and $2 \%$ For the decline, Developing, still walking on the spot.

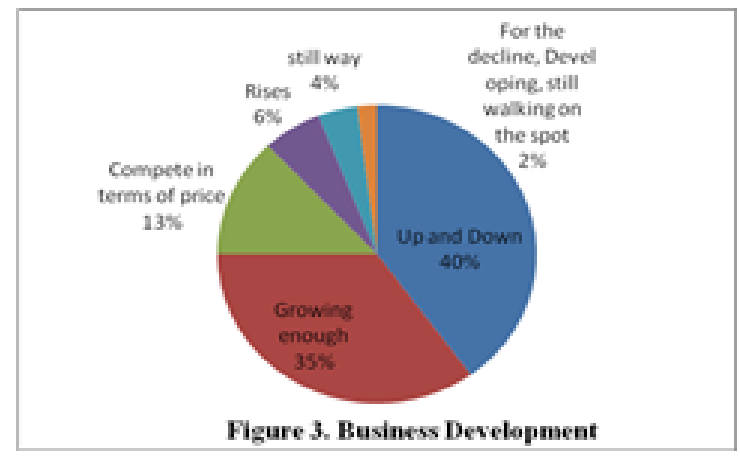

Figure 3. Business Development

\section{Year to Start a Business}

Businesses that are around District of Kisaran Barat, can be considered the effort that has begun long ago. Inspiration from the parents before the main assets to the next generation to do business. But sometimes many businesses are afraid to innovate due to fear of the banks if there is collateral as well as a quick understanding of the businesses owned satisfied. Business year starting from the business are:

a. In 1970 as much as $23 \%$ and is the work done for generations

b. In 2010 as much as $21 \%$ due to the pioneering efforts early and become a benchmark in the development of business 
c. In 1980 as much as $18 \%$ due to the effort that is inherited from parents and are followed by the next generation

Another few years of starting the business was in 2012 as much as $9 \%$, in 2008 as much as $5 \%$, in 2013 as much as 3\%, in 2001 by $2 \%$ and $1 \%$ for 2011, 2007, 2000, 1995 and 1990.

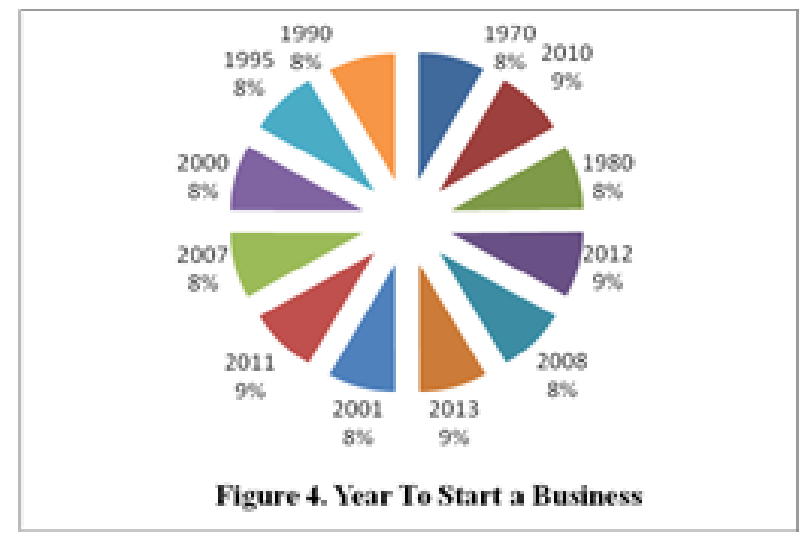

Figure 4. Year to Start A Business

\section{Responden Ages}

For the age of the respondents, can be seen later on that instinct in business is the generation over a range of 30 years and above. The need for a structured coaching to young age of fond for entrepreneurship to be a starting point in promoting entrepreneurship. We often hear that the economic crisis is not exposed at the real sector is due to have a strong foundation and remains much in demand if qualitatively can compete in terms of price. As for the age of the respondent that sells are:

a. Age over 50 years as much as $34 \%$

b. Age $40-50$ years $33 \%$

c. Age $30-40$ years by $27 \%$

Age above can be categorized age is the end point while for ages 20-30 Golden Moment as much as $6 \%$ It could be an idea for us all to increase interest in entrepreneurship from an early age.

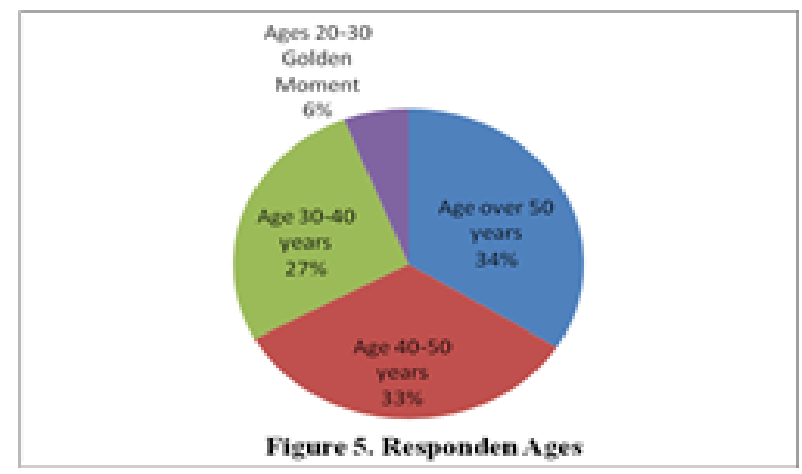

Figure 5. Responden Ages

\section{Total Labour}

Labor is a major factor in increasing the production of entrepreneurship. It will further improve the efficiency and effectiveness of business generated. However, the resulting specialized workforce we need to see how much labor to increase value to the business. The number of employment generated is

a. 1 workforce totaled as many as $55 \%$

b. Amounted to 2 work force as many as $45 \%$

Here, it could be concluded that with the absorption of labor could minimize unemployment. If the development is structured, then the problem of unemployment can be resolved quickly and will be the creation of a new industry that has global competitiveness. 


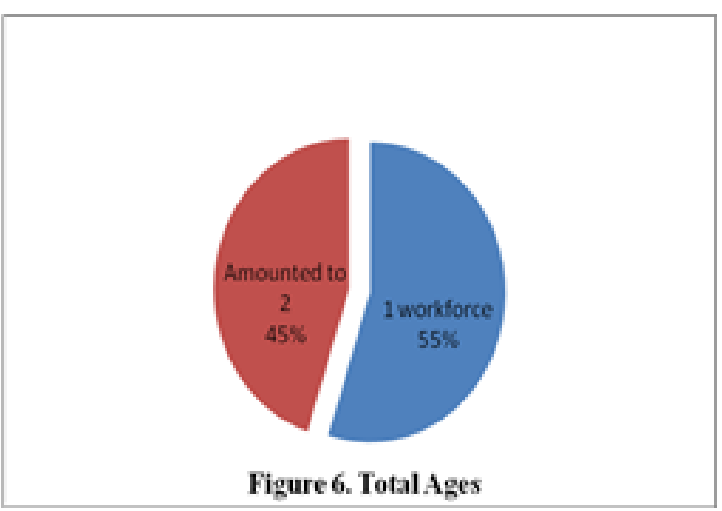

Figure 6. Total Ages

\section{Type of Business Development Assistance}

For this type of assistance that is around the West range based on the information never gets aid but only a handful of businesses and help existing only come from the Department of Industry (Industry and Trade) and the Party of Banking. Of the work of a little grocery business and Shoe Making Bunut ever felt relief from related parties. Here are the results of the monitoring of the type of business development assistance:

a. No aid equal to $87 \%$ is a response to the result of the answers to each small enterprise like Juice Making, Pick Up, Making Bricks, Brown Sugar Making of Oil Palm and a handful of general trade. Help from Bank Rakyat Indonesia amounted to $8 \%$ is the answer to the shoe making industry Bunut. $8 \%$ almost had to share the shoe entrepreneur Bunut. It is a picture that this industry is an industry that is considered of a growing banking industry and prospects in the disbursement of funds.

b. For the Department of Industry (Industry and Trade) of $2 \%$ to provide assistance to industry and the Shoemaker Bunut still experiencing problems and leave the bad credit payments

For Syariah Mandiri Bank, Danamon Bank, Ulam each providing assistance to the Shoe Industry Bunut and is currently still ongoing assistance loan in the long term.

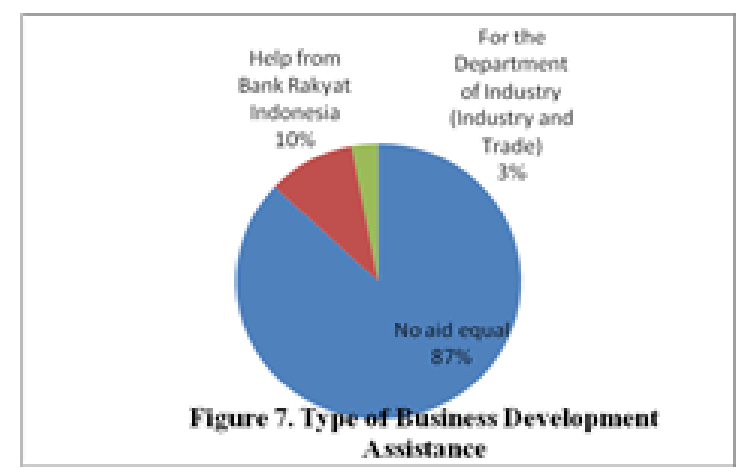

Figure 7. Type Of Business Development Assistance

\section{Expected Type Help Private Agencies / Governtment Ones}

The respondents argued today, the lack of coaching is right for the business they pursue so the results are not in accordance with the wishes of consumers due to price competition, the lack of information on market need up role for both government and private/state to improve people's needs globally. Following the desire of citizens to various parties who wish to provide assistance:

a. Capital, Training, Marketing 54\% of the overall response exist and are expected to increase their efforts

b. Stone Maker $26 \%$ is the answer for stone maker due to fluctuating weather conditions and the machine is expected to print and dry immediately 
c. Normalize coal price of $15 \%$ is the answer to the creators of the rock due to the uncertain market fluctuations

Some other desirable desire Business Tools: Oven, Gas stove, Gas 5\% and home business premises by $5 \%$

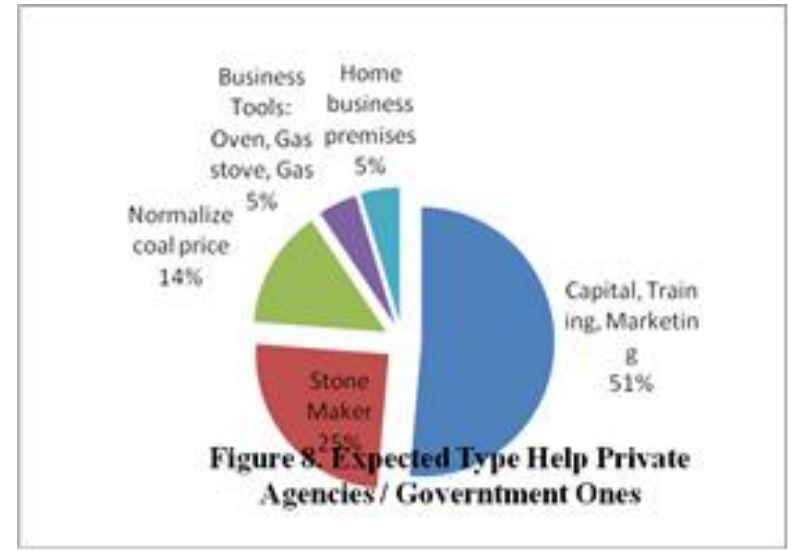

Figure 8. Expected Type Help Private Agencies/Government Ones

\section{DISCUSSION}

As social philanthropy that relies on private donations, volunteers and non-profit organizations to meet the needs, find solutions to social problems, and create new social opportunities for the developed business need to be invested by the hoping by entrepreneurs. Capital, Training, Marketing can be the best solution to enhance the business. Most of them hoped to be given from the governmental dan private company around Kisaran Barat. By giving the social philanthropy, They can give the responsibility to the environtment like the research [2], [3].

To improve a company's development, an education that affect the R\&D. On the previous research has shown that, although small companies are generally less likely to engage in research and development of large companies so they tend to use their innovative input more efficiently than large companies. By social economic mapping can be contributed to the people and others to support the economic development. The data collected can be one of the support to know the effective assistant by the environmenment to get the innovation, like the research [4], [5]

If innovation by pointing to the research and development to get optimal results, required capital aspect of small medium entreprises to minimize unemployment. As the capital that can moved to real sector and increase the the ages of entrepreneur and the solution for the up and down business development. The innovation can change the common business time that seemed to be the same from year to year so that the number of population can be taken to laborforce and the solution to reduce the jobless as the problem in economic development.

\section{CONCLUSION AND RECOMMENDATION}

\section{Conclusion}

Kisaran Barat has a fundamental role to improve the socio-economic around existing areas. According to some studies, the West has a range of areas such as J1. Tjokroaminoto, Jl. Sibogat, Jl. Diponegoro. In other words, the need for the empowerment becomes a cornerstone in the provision of assistence that can be given in a segmented and is the best breakthrough for Asahan society in line with the National Entrepreneurship Movement which is issued by the government program.

In the characteristic ability of communities around the District of West Range, can be seen from 8 major characteristics that From the results of this study indicate that the business category is making bricks, inspiration opening business: The ages business effort, Business Development: up and down, Year to Start a Business: In 1970, age of Respondents is over 50 years, total workforce: 1 labor, type of business development assistance: no aid, types of help expected private agencies/government one: capital, training, marketing. 


\section{Recommendation}

a. For private and government companies can focus the corporate social responsibily to give capital, training, marketing as the hope from the entrepreneur.

b. The business education must be the first orientation not only for the new ages for business but also the developed one so that there's the innovation to increase the hard competition in the business world.

\section{REFERENCES}

http://asahankab.bps.go.id/.

Kasali, R. (2012). Cracking Value (Bersih, Bersinar, Dan Kompetitif). Jakarta: Pt Gramedia Jakarta.

Huraerah, A. (2008). Pengorganisasian \& Pengembangan Masyarakat (Model \& Strategi Pembangunan Berbasis Kerakyatan). Bandung: Pendidikan Anggota Ikapi Mencerahkan Kehidupan.

Lerner, J. (2010). The Future Of Public Efforts To Boost Entrepreneurship And Venture Capital. Small Bus Econ , 255-264.

Sukirno, S. (2011). Ekonomi Pembangunan (Proses, Masalah, Dan Dasar Kebijakan). Jakarta: Prenada Media Group.

Sugiyono. (2009). Metode Penelitian Pendidikan (Pendekatan Kuantitatif, Kualitatif Dan R\&D). Bandung: Afabeta Bandung.

Http://Pemkab-Asahan.Go.Id. (2014). 